\title{
Relationships between different body characteristics and milk yield traits in Kilis goats
}

Kilis keçilerinde farklı vücut özellikleri ile süt verim özellikleri arasındaki ilişkiler

\author{
Hatice YILMAZ TiLKi ${ }^{1}$, Mahmut KESKiN ${ }^{2}$ \\ ${ }^{1}$ Mustafa Kemal University, Graduate School of Natural and Applied Sciences Antakya, Hatay, TURKEY \\ ${ }^{2}$ Mustafa Kemal University, Department of Animal Science, Faculty of Agriculture Antakya, Hatay, TURKEY
}

MAKALE BILGISI / ARTICLE INFO

\section{Makale tarihçesi / Article history:}

DOI: $10.37908 /$ mkutbd.893730

Geliş tarihi /Received:09.03.2021

Kabul tarihi/Accepted:01.04.2021

\section{Keywords:}

Kilis goat, body measurements, udder measurements, lactation.

\footnotetext{
Corresponding author: Mahmut KESKIN

E mail: mkeskin@mku.edu.tr
}

\author{
ÖZET / A BSTRACT
}

Atıf / Citation: Tilki Yılmaz H, Keskin M (2021) Kilis keçilerinde farklı vücut özellikleri ile süt verim özellikleri arasındaki ilişkiler. MKU. Tar. Bil. Derg. 26(2) : 272-277. DOI: 10.37908/mkutbd. 893730

\section{INTRODUCTION}

It is seen that the number of goats in the world has increased proportionally faster than other ruminant animal species in recent years. The growing interest in goat is not accidental. It can be said that the impact of global climate change on the ecosystem and biological diversity plays a role in this interest (Çavuşoğlu and Akyürek, 2017). On the other hand, goat milk attracts more and more attention in the world due to its richness in nutrient content and its characteristics similar to human milk. There is an increasing interest in goat milk, which is different from cow and sheep milk due to its nutritional characteristics, especially its protein types and lactose content (Önür, 2015; Bozkaya, 2009).

With the increasing number of goats in its sector, there are also breeding studies aimed at increasing the yield characteristics. It is known that accurate and reliable recording is an obligation in animal improvement studies. The number of farms recording in goat breeding in Turkey is extremely limited. Most of the enterprises that keep records in the country are the farms involved in the "National Animal Breeding Project" carried out in corporation with Ministry of Agriculture and Forestry, Universities and Sheep and Goat Breeders Associations (Bebek and Keskin, 2018; Aydın and Keskin, 2018). 
Studies conducted within the scope of the "Natural Animal Breeding Project" have shown that births occurring in a wide period of year in sheep and goat breeding (Keskin et al., 2017; Gül et al., 2020) is another important problem encountered in breeding studies.

The use of genetic parameters calculated by different methods in animal breeding is extremely important (Behrem, 2021). However, it is impossible to ensure it every time in small ruminant improvement studies in Turkey. For this reason, subjective criterias are used generally in the selection of small ruminants as breeding stock in the field. Subjective criteria are mostly applied by taking advantage of the knowledge of experienced breeders to select the animals to be breeding stock. These breeders evaluate the animals by looking at features such as leg structure, head size, ear shape, body size, breast girth, udder shape. Özcan and Torun (1992) also reported that in ruminant animals, features such as body shape, rib angle, head size and neck length can be taken into account in separating beef and dairy animals from each other. In addition, since it is known that milk yield in dairy goats is closely related with udder and teat characteristics (Wang, 1989; Akbaş et al., 2019), these characteristics should also be taken into consideration to select the breeding stock.

In this study, it was aimed to determine the relationships between different body measurements and milk yield characteristics of Kilis goat, which is an important material for goat milk production of Turkey.

\section{MATERIALS AND METHODS}

The animal material of the study consisted of 100 head Kilis goats aged 2, 3 and 4, which are rearing in Kilis province ( $36^{\circ} 45^{\prime} 09^{\prime \prime}$ North and $37^{\circ} 06^{\prime} 40^{\prime \prime}$ East). The study was carried out with the approval of the Hatay Mustafa Kemal University Ethics committee (MKUHADYEK-2018/11-2).

In the study, different morphological characteristics, body measurements and weight of goats were determined. To determine the body weight, all goats were weighed before mating date by a weigher with precision of $100 \mathrm{~g}$. Withers height, loin height, rump height, body length, front shoulder width and chest depth were measured by using measuring sticks. Chest circumference, front rump width, middle rump width, back rump width, shin circumference, neck width and circumference at the junction of the head and body, neck length (bottom-top), ear length and width were determined by tape measure. Skin thinness is determined with a digital calliper on the udder. These measurements were made after the goats had been calmed down in a flat area. Also as udder measurements; teat length, distance between teats, udder length, udder width, udder width over teats, teat diameter was determined by tape measure (Epstein, 1985).

After parturitions, the goats received $500 \mathrm{~g} /$ day per animal from feed containing $2600 \mathrm{kcal} \mathrm{ME}$ and $15 \%$ crude protein in addition to pasture. Also all goats could reach to hay and cotton seed as roughage in the first 3 months of lactation.

During lactation, milk yield controls were made at 28-day intervals. Lactation milk yield and lactation length were calculated according to the ICAR-AT method that was used also by Keskin et al. (2017). Individual lactation milk yields of the goats were calculated according to the Flechman method.

Statistical analysis of the data was evaluated by General Linear Model and Duncan test procedures in the SPSS package program (Version 22.00, SPSS, IBM, NY, USA).

\section{RESULTS and DISCUSSION}

The results obtained in this study, which investigated the relationship between body and udder characteristics and milk yield characteristics in Kilis goats, are presented in tables. Least squares averages of live weight and some body measurements, due to the goats' ages are given in Table 1. As seen from the table, body weight, front shoulders width, chest circumference, shin circumference, neck lower length and neck circumference increased with age $(P<0.05)$. At the same time, although it is not statistically significant, it is seen that there are increases also in other characteristics depending on age. These findings give the opportunity to express that the development of chest and neck region may be more effective in the change of body weight due to age in Kilis goats. These findings are in line with the statements of Karadağ and Soysal (2018) for Honamlı goats and Ünalan and Ceyhan (2017) for Kilis goat stating that ages of goats affect their body size and weight. As can be seen from the table, age did not have any effect on ear length, ear width and skin thinness in Kilis goats $(P>0.05)$. 
Table 1. Effects of age on body weight $(\mathrm{kg})$ and different body measurements (mean \pm standard error)

\begin{tabular}{|c|c|c|c|}
\hline \multirow[t]{2}{*}{ Traits } & \multicolumn{3}{|c|}{ Age } \\
\hline & 2 & 3 & $\geq 4$ \\
\hline Goat number (head) & 8 & 26 & 66 \\
\hline Live weight (kg) & $48.5 \pm 2.72^{a}$ & $49.2 \pm 1.18^{a}$ & $54.6 \pm 0.85^{b}$ \\
\hline Body length $(\mathrm{cm})$ & $84.4 \pm 1.59 a$ & $83.2 \pm 0.93 \underline{a}$ & $85.7 \pm 0.52^{a}$ \\
\hline Withers height $(\mathrm{cm})$ & $68.2 \pm 1.74 \underline{a}$ & $67.0 \pm 0.50 \underline{a}$ & $68.4 \pm 0.48^{a}$ \\
\hline Rump height $(\mathrm{cm})$ & $68.1 \pm 0.97 \underline{a}$ & $67.8 \pm 0.49 \underline{a}$ & $68.8 \pm 0.38^{\mathrm{a}}$ \\
\hline Loin height $(\mathrm{cm})$ & $63.8 \pm 1.50^{a}$ & $64.3 \pm 0.59 \underline{a}$ & $66.0 \pm 0.46^{\mathrm{a}}$ \\
\hline Front shoulders width $(\mathrm{cm})$ & $15.6 \pm 0.56 \underline{a}$ & $17.6 \pm 0.36^{b}$ & $18.3 \pm 0.21^{b}$ \\
\hline Chest circumference $(\mathrm{cm})$ & $84.3 \pm 1.41 \underline{a}$ & $84.7 \pm 0.76 a$ & $88.6 \pm 0.55^{b}$ \\
\hline Chest depth $(\mathrm{cm})$ & $28.9 \pm 0.59 \underline{a}$ & $28.5 \pm 0.45 \underline{a}$ & $30.2 \pm 0.32^{a}$ \\
\hline front rump width, (cm) & $13.4 \pm 0.53^{a}$ & $13.7 \pm 0.247 \underline{a}$ & $14.1 \pm 0.19 \underline{a}$ \\
\hline Middle rump width $(\mathrm{cm})$ & $21.6 \pm 0.37 \underline{a}$ & $21.5 \pm 0.24 \underline{a}$ & $22.0 \pm 0.21^{a}$ \\
\hline Back rump width (cm) & $7.2 \pm 0.28 \mathrm{a}$ & $7.3 \pm 0.21 \underline{a}$ & $7.4 \pm 0.12^{a}$ \\
\hline Rump height $(\mathrm{cm})$ & $68.1 \pm 0.97 \underline{a}$ & $67.8 \pm 0.49 \underline{a}$ & $68.8 \pm 0.38$ a \\
\hline Shin circumference $(\mathrm{cm})$ & $10.6 \pm 0.26 \mathrm{a}$ & $10.0 \pm 0.14^{\mathrm{ab}}$ & $10.4 \pm 0.10^{b}$ \\
\hline Neck upper line length $(\mathrm{cm})$ & $19.0 \pm 0.38 \mathrm{a}$ & $19.2 \pm 0.31 \underline{a}$ & $19.8 \pm 0.23 a$ \\
\hline Neck lower line length $(\mathrm{cm})$ & $24.9 \pm 0.35$ & $26.6 \pm 0.35^{b}$ & $27.5 \pm 0.22^{b}$ \\
\hline Neck circumference-1 (cm) & $30.3 \pm 0.53 \underline{a}$ & $30.8 \pm 0.36 \mathrm{a}$ & $32.4 \pm 0.23^{b}$ \\
\hline Neck circumference-2 $(\mathrm{cm})$ & $31.6 \pm 0.78 \underline{a}$ & $32.2 \pm 0.43^{\mathrm{ab}}$ & $33.9 \pm 0.41^{b}$ \\
\hline Neck circumference-3 $(\mathrm{cm})$ & $44.6 \pm 0.84$ & $45.4 \pm 0.53^{\mathrm{ab}}$ & $47.30 \pm 0.39^{b}$ \\
\hline Ear length $(\mathrm{cm})$ & $25.7 \pm 2.09 a$ & $25.0 \pm 1.41 \underline{a}$ & $25.6 \pm 0.92^{a}$ \\
\hline Ear width $(\mathrm{cm})$ & $9.3 \pm 0.77 \underline{a}$ & $8.8 \pm 0.48 \underline{a}$ & $8.8 \pm 0.30 \mathrm{a}$ \\
\hline Skin thinness (mm) & $4.5 \pm 0.45 \underline{a}$ & $4.0 \pm 0.12^{a}$ & $4.0 \pm 0.09 \underline{a}$ \\
\hline
\end{tabular}

Note: Different letters on the same line as superscript indicate different groups $P<0.05$ significance level. Neck circumference-1, neck circumference at the junction of the head and neck; neck circumference-2, circumference at medial part of neck; neck circumference-3, neck circumference at the junction of the chest and neck.

On the other hand, as can be seen from Table 2, some udder measurements were affected by the age of the goat. In the study, it was determined that the length of the teats, the distance between the teats, udder width and udder circumference were not affected by age, while the udder length and teat diameter increased with age. Increasing udder length depending on age is important in terms of showing that the udder sags downward and widen in animals as the lactation number increases.

The milk yield characteristics determined in the experimental goats were not affected by the age of the goats (Table 2). This may be due to the low number of animals in the age group of 2 years. Lactation milk yield and lactation length reported in the current study were higher than the values informed as 293.7 - 408.3 liters and 212.5 - 256.5 days by Gül et al (2016) for Kilis goats raised in the same region. Also, Keskin et al. (2017) notified these traits as 347.0 liters and 221.9 days for the same breed. We know that, as in other species, lactation characteristics of goats can vary from farm to farm or from year to year. Because in extensive or semi-intensive animal rearing, the roughage needs of animals are mostly provided from the pasture. And, the quality and quantity of pastures are closely related to climatic conditions. For this reason, the differences between the present study and these literatures for milk yield characteristics might have resulted from differences in herd management practices and climatic conditions from year to year. 
Table 2. Effects of age on udder sizes and some lactation characteristics (mean \pm standard error)

\begin{tabular}{lccc}
\hline & \multicolumn{3}{c}{ Age } \\
\cline { 2 - 4 } Traits & 2 & 3 & $\geq 4$ \\
\hline Goat number (head) & 8 & 26 & 66 \\
Teat length (cm) & $4.1 \pm 0.27 \underline{\mathrm{a}}$ & $4.4 \pm 0.19 \underline{\mathrm{a}}$ & $4.6 \pm 0.17^{\mathrm{a}} \underline{\mathrm{a}}$ \\
Distance between two teats (cm) & $15.6 \pm 0.75^{\mathrm{a}}$ & $17.3 \pm 0.48^{\mathrm{a}}$ & $17.3 \pm 0.34^{\mathrm{a}}$ \\
Udder length (cm) & $19.3 \pm 0.82^{\mathrm{a}}$ & $20.3 \pm 0.54^{\mathrm{ab}}$ & $22.1 \pm 0.45^{\mathrm{b}}$ \\
Udder width (cm) & $13.0 \pm 0.42^{\mathrm{a}}$ & $13.7 \pm 0.29 \underline{\mathrm{a}}$ & $13.2 \pm 0.19^{\mathrm{a}}$ \\
Udder circumference (cm) & $34.9 \pm 1.29 \underline{\mathrm{a}}$ & $37.6 \pm 0.84^{\mathrm{a}}$ & $37.0 \pm 0.56^{\mathrm{a}}$ \\
Diameter of teat (cm) & $4.4 \pm 0.29^{\mathrm{a}}$ & $4.9 \pm 0.15^{\mathrm{ab}}$ & $5.1 \pm 0.11^{\mathrm{b}}$ \\
Lactation milk yield (kg) & $200.0 \pm 9.32^{\mathrm{a}}$ & $213.1 \pm 6.05^{\mathrm{a}}$ & $211.9 \pm 4.24^{\mathrm{a}}$ \\
Lactation length (days) & $256.4 \pm 8.27^{\mathrm{a}}$ & $253.6 \pm 3.32^{\mathrm{a}}$ & $251.4 \pm 1.99^{\mathrm{a}}$ \\
Daily milk yield (g) & $781.2 \pm 31.60^{\mathrm{a}}$ & $844.2 \pm 26.51^{\mathrm{a}}$ & $846.9 \pm 18.27^{\mathrm{a}}$ \\
\hline
\end{tabular}

Different letters in the same line written as superscript show statistical differences at the level of 0.05 .

Some important correlations were determined between some body measurements in the study (Table 3 ). In this context, the relationships between body weight and body length, width between front shoulders and chest circumference were significant $(P<0.01)$. Likewise, the relationships between body length and rump height and chest circumference; relationship between loin height and rump height; the relationship between front shoulders width and chest circumference were also determined to be significant $(P<0.05$ or $P<0.01)$.
Similarly, strong and positive correlations were reported for Kanni Adu goat reared in India by Thiruvenkadan et al. (2005), for Yankasa sheep by Afolayan et al. (2016), for Saanen crossbred goats by Yıldız (2008), for Honamlı goats reared in the Mediterranean region by Karadağ and Soysal (2018), for Kilis goats by Ünalan and Ceyhan (2017) and Daşkıran and Yılmaz (2018). The researchers particularly have been noted the high correlation between live weight with chest circumference and body length.

Table 3. Correlations between different body measurements in Kilis goats

\begin{tabular}{lcccccc}
\hline & $\mathrm{LW}$ & $\mathrm{BL}$ & $\mathrm{LH}$ & $\mathrm{RH}$ & $\mathrm{FS}$ & $\mathrm{CC}$ \\
\hline LW & 1 & $0.55^{* *}$ & 0.98 & 0.17 & $0.35^{* *}$ & $0.65^{* *}$ \\
BL & 1 & 0.19 & $0.23^{*}$ & 0.19 & $0.45^{* *}$ \\
LH & & & 1 & $0.80^{* *}$ & -0.15 & 0.98 \\
RH & & & & 1 & -0.08 & 0.13 \\
FS & & & & & 1 & $0.43^{* *}$ \\
CC & & & & & & 1 \\
\hline
\end{tabular}

$\mathrm{LW}$, live weight; BL, body length; LH, loin height; RH, rump height; $\mathrm{FS}$, width between front shoulders; $\mathrm{CC}$, chest circumference; ${ }^{*}, \mathrm{P}<0.05 ;{ }^{* *}, \mathrm{P}$ $<0.01$.

As can be seen in Table 4, statistically significant relationships have been determined between lactation milk yield with live weight, body length, front shoulder width, chest circumference and the udder measurements. Also, similar relationships were determined between daily milk yield and some of these characteristics $(\mathrm{P}<0.05$ or $\mathrm{P}<0.01)$. Similarly, Winaya et al. (2017) stated that there are important relationships between some body measurements and milk yield characteristics in Jakang and Etawah goats raised in Indonesia. The researchers stated that there is a statistically significant correlation between udder circumference and milk yield for these goats $(r=0.42)$ and this measure can be used for breeder selection for milk yield. 
Table 4. Correlations between different body measurements and lactation characteristics

\begin{tabular}{|c|c|c|c|c|c|c|c|c|c|c|c|}
\hline & LW & $\mathrm{BL}$ & $\mathrm{LH}$ & $\mathrm{RH}$ & $\mathrm{FS}$ & $\mathrm{CC}$ & $\mathrm{DU}$ & UL & UW1 & UW2 & TC \\
\hline LMY & $0.20^{*}$ & $0.20^{*}$ & -0.19 & -0.09 & $0.24^{*}$ & $0.30^{* *}$ & $0.49^{* *}$ & $0.32^{* *}$ & $0.26^{* *}$ & $0.21^{*}$ & $0.21^{*}$ \\
\hline LL & 0.12 & -0.03 & $-0.29^{* *}$ & $-0.23^{*}$ & 0.18 & 0.00 & 0.16 & -0.02 & 0.04 & 0.11 & 0.11 \\
\hline DMY & 0.14 & $0.21^{*}$ & -0.05 & 0.03 & 0.14 & $0.27^{* *}$ & $0.39^{* *}$ & $0.30^{* *}$ & $0.23^{*}$ & 0.16 & 0.16 \\
\hline
\end{tabular}

LMY, lactation milk yield; LD, lactation length; DMY, Daily milk yield; LW, live weight; BL, body length; LH, loin height; RH, rump height; FS, width between front shoulders; CC, chest circumference; DU, distance between two teats; UL, udder length; UW1, udder width; UW2, udder width over the teats; TC, teat circumference; ${ }^{*}, \mathrm{P}<0.05 ; * *, \mathrm{P}<0.01$.

As similar to the current results, they were reported significant correlations between milk yield and some udder characteristic that were teat circumference and udder circumference in Hair goat (Atay et al., 2011). On the other hand, Akbaş et al. (2019) stated in their study with Honamlı goats that the characteristics of udder and teat can vary from province to province and even from herd to herd. Also, Aktaş ve ark., (2012) reported important correlations between udder width, udder circumference, udder angle and udder volume in Turkish Saanen goats reared in Kahramanmaraş province. Furthermore it was informed by Wang (1989) that there is a relationship between some udder characteristics and 180-day milk yield. It is stated by Alıç (2014) that there were significant correlations between udder upper height, udder circumference, udder bottom height and udder depth in Maltese $\mathrm{x}$ Saanen crossbred goats. Researchers have suggested that udder and teat features can be used to select breeding stocks.

As conclusions in this study, they were significant correlations (a) between lactation milk yield with body weight, body length, udder width, udder circumference; and (b) between lactation milk yield and distance between the teat, udder length, udder width, udder width over the teat and teat diameter. It can be stated that these features can be used in breeding stock selection according to subjective criteria.

\section{ÖZET}

Amaç: Bu çalışmada Kilis keçilerinin bazı vücut ve meme ölçüleri ile süt verim özellikleri arasındaki korelasyonlar araştırılmıştır.

Yöntem ve Bulgular: Çeşitli vücut ölçüleri ile bazı laktasyon özellikleri arasındaki ilişkilerin araştırıldığı bu çalışma Kilis ilinde yetiştirilen Kilis keçileri ile yürütülmüştür. Çalışmanın hayvan materyalini 100 baş Kilis keçisi oluşturmuştur. Vücut ve meme ölçüleri ölçü bastonu veya ölçü şeridi kullanılarak belirlenmiştir. Laktasyon özellikler ICAR-AT metodu kullanılarak hesaplanmıştır. Çalışma sonunda Kilis keçilerinin \%58 ikizlik oranına sahip oldukları ve laktasyon süt verimlerinin $200.0 \pm 9.32$ ile $213.1 \pm 6.05$ litre ve laktasyon süresinin ise $251.4 \pm 1.99$ ile $256.4 \pm 8.27$ gün arasında değiştiği belirlenmiştir.

Genel Yorum: Çalışmada, laktasyon süt verimi ile canlı ağırlık, vücut uzunluğu, ön göğüs genişliği arasında $\% 5$ ve gögüs çevresi arasında \%1 önem seviyesinde pozitif ve önemli korelasyonlar belirlenmiştir. Ayrıca laktasyon süt verimi ile meme ölçüleri arasında pozitif ve önemli $(\mathrm{P}<0.01)$ korelasyonlar da belirlenmiştir.

Çalışmanın Önemi ve Etkisi: Subjektif kriterlere göre damızlık hayvan seçiminde bu özelliklerin kullanılabileceği söylenebilir.

Anahtar Kelimeler: Kilis keçisi, vücut ölçüleri, meme ölçüleri, laktasyon

\section{ACKNOWLEDGEMENT}

This manuscript has been prepared as part of a MSc thesis entitled as "Relationships Between Different Body Characteristics and Yield Characteristics in Kilis Goats". The authors would like to thank HMKU Coordinatorship of Scientific Research Projects (Project No: 19.YL.014) which provides financial support to the study.

\section{CONFLICT OF INTEREST}

The author declares that there is no conflict of interest in the study.

\section{REFERENCES}

Afolayan RA, Adeyinka IA, Lakpini CAM (2006) The estimation of live weight from body measurements in Yankasa sheep. Czech J Anim Sci. 51(8): 343-348.

Akbaş AA, Elmaz Ö, Sarı M, Saatçı M (2019) Assesment of some udder and teat traits of Honamlı goats in terms of dairy characters. J Res Vet Med. 38(2): 57-64.

Aktaş ZM, Kaygısız A, Baş S (2012) Kahramanmaraş yetiştirici şartlarında Türk Saanen keçilerinin süt verim özellikleri, bazı meme ölçüleri ve SHS arasındaki ilişkiler. KSÜ Doğa Bil Derg. 15(4): 7-17.

Alıç DU (2014) Aydın'da yetiştirilen Maltız x Saanen melez keçilere ait bazı meme ölçüleri ile süt verimi arasındaki ilişkilerin araştırılması. Animal Health Prod and Hyg. 3(1): 258-263. 
Atay O, Gökdal Ö, Özuğur AK, Eren V (2011) Yetiştirici koşullarında kıl keçilerin meme özellikleri ile süt verim özellikleri arasındaki ilişkiler. 7. Ulusal Zootekni Bilim Kongresi, 14-17 Eylül 2011, Çukurova Üniversitesi, Adana.

Aydın MK, Keskin M (2018) Muğla ilinde küçükbaş hayvan yetiştiriciliğinin yapısal özellikleri. Mediterranean. 31(3): 317-323.

Bebek DT, Keskin M (2018) Mersin ilinde koyun yetiştiriciliğinin mevcut durumu bazı verim ve yapısal özellikleri. MKÜ Ziraat Fakültesi Dergisi. 23(2): 315329.

Behrem S (2021) Estimation of genetic parameters for pre-weaning growth traits in Central Anatolian Merino sheep. Small Rumin Res. 197: 1-5.

Bozkaya F (2009) Keçilerde kazein genlerindeki çeşitlilik ve önemi. Atatürk Üniversitesi Vet. Bil. Derg. 4(2): 133-145.

Çavuşoğlu YS, Akyürek H (2017) Koyunlarda ve keçilerde beslenme davranışları. Harran Tarım ve Gıda Bilimleri Dergisi 22(1): 137-151.

Daşkıran i, Yılmaz A (2018) Ekstansif koşullarda yetiştirilen Kilis keçilerinde canlı ağırlık ve vücut ölçüleri arasındaki korelâsyonlar ve bazı tanımlayıcı ölçüler. Tekirdağ Ziraat Fakültesi Dergisi 15(1): 51-56.

Epstein H (1985) The Awassi sheep with special reference to the improved dairy type. FAO Animal Production and Health Paper, Food and Agriculture Organization of the United Nations. Rome. 57

Gül S, Keskin M, Göçmez Z, Gündüz Z (2016) Effects of supplemental feeding on performance of Kilis goats kept on pasture condition. Italian Journal of Animal Science 15(1): 110-115.

Gül S, Keskin M, Biçer O, Gündüz Z, Behrem S (2020) Effects of different lambing season on some reproductive characteristics of ewes and growth performance of lambs in Awassi sheep. Livestock Studies 60(1): 32-36.

Karadağ O, Soysal Mi (2018) Honamlı keçilerinin bazı döl verimi,büyüme ve morfolojik özelliklerinin belirlenmesi. Tekirdağ Ziraat Fakültesi Dergisi 15(1): 135-142.

Keskin M, Kaya Ş, Özcan L, Biçer O (1996) Hatay bölgesinde yetiştirilen keçilerin bazı morfolojik ve fizyolojik özellikleri üzerine bir araştırma. MKÜ Ziraat Fakültesi Derg. 1(1): 69-84.

Keskin M, Gül S, Biçer O, Daşkıran i (2017) Some reproductive, lactation, and kid growth characteristics of Kilis goats under semiintensive conditions. Turk J Vet Anim Sci. 41: 248-254.

Önür ZY (2015) Keçi ve koyun sütlerinin kimyasal bileşimleri. Gıda 40(6): 363-370.

Özcan L (1989) Küçükbaş Hayvan Yetiştirme I (Keçi Üretimi). Çukurova Üniversitesi Ziraat Fakültesi Ders Kitabı No: 111, Adana.

Özcan L, Torun O (1992) Hayvan Yetiştirme. Çukurova Üniversitesi Ziraat Fakültesi Ders Kitabı No: 112, Adana.

Özdemir FH, Keskin M (2017) Kilis ve Gaziantep illerinde yetiştirilen Kilis keçilerinin bazı morfolojik ve fizyolojik özellikler bakımından karşılaştırılması. MKÜ Ziraat Fakültesi Derg. 23(1): 115-123.

Thiruvenkadan AK (2005) Determination of best-fitted regression model for estimation of body weight in Kanni Adu kids under farmer's management system. Livestock Research for Rural Development 17(7).

Ünalan A, Ceyhan A (2017) Kilis keçilerinin canlı ağırlık ve bazı vücut ölçüleri üzerinde cinsiyet etkisinin belirlenmesi. Harran Tarım ve Gıda Bilimleri Derg. 21(2): 219-226.

Wang PQ (1989) Udder characteristics in Togenburg dairy goats. Small Rumin Res. 2(2): 181-190.

Winaya A, Prihartini I, Ramadhan SW, Adhim ATF, Rico MJI (2017) Linear body measurement of Indonesian Etowah crossbred goat [Capra Aegagrus Hircus (linnaeus, 1758)] and its relationship with milk production ability. Proceedings of the Pakistan Academy of Sciences: B. Life and Environmental Sciences 54(4): 301-309

Yıldız G (2008) Tekirdag ilinde halk elinde yetiştirilen Karacabey Merinos X Kıvırcık melez kuzular ile Saanen melez oğlaklarında canlı ağırlık-vücut ölçüleri ilişkileri ve bazı büyüme modellerinin belirlenmesi üzerine bir araştırma. Yüksek Lisans Tezi , Namık Kemal Üniversitesi Fen Bil Enst. 76 s. 